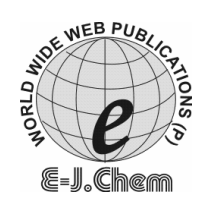

http://www.e-journals.net
ISSN: 0973-4945; CODEN ECJHAO

E-Journal of Chemistry

2008, 5(S1), 997-1007

\title{
Synthesis of Compounds Containing Fluorine, Vinylsulfone Groups and Transition Metal Complexes and their Applications to Textiles
}

\author{
E.YILDIZ* and N.BOZOK \\ Department of Chemistry, Arts and Science Faculty, \\ Cukurova University,Balcali 01330, Adana, Turkiye \\ eeyildiz@cu.edu.trFax:+903223386070.
}

Received 24 December 2007; Revised 10 March 2008; Accepted 5 May 2008

\begin{abstract}
A ligand which has reactive dye character and its transition metal complexes such as $\mathrm{Cu}(\mathrm{II}), \mathrm{Co}(\mathrm{II}), \mathrm{Cr}(\mathrm{III}), \mathrm{Ni}(\mathrm{II})$ containing vinylsulfone and fluorine groups were synthesized. The diazotation reaction has been studied at $0-5^{\circ} \mathrm{C}$ carefully. Completion of the reaction was monitored by the TLC method. FT-IR, UV, ${ }^{1} \mathrm{H}-\mathrm{NMR}$, TGA and microanalysis methods were used for determination of the synthesized compounds. We assumed that copper complex indicated dimeric structure based on magnetic susceptibility result. All the synthesized compounds which have dye character were applied on cotton, polyamide and nylon fibers. Their dyeing and fastness properties were investigated according to international standards. These properties gave good results for all synthesized dyes except light fastnesses of chromium and nickel complex dyes.
\end{abstract}

Keywords: Reactive dye, Vinylsulfone, Fluorine, Metal complex, Synthesis.

\section{Introduction}

Fiber-reactive dyes provide clear, bright shades, have good fastness properties, allow versatility in application methods and contain lower substantivity levels than do direct dyes. The higher emphasis on reactive dyes reflects the most consumers' interest in bright, highfastness fashion shades in cotton fibers ${ }^{1}$.

In 1957 Hoechst (now DyeStar) introduced remazol dyes for cotton, which contain a vinylsulfone reactive group capable of forming covalent bonds with cellulosic fibers under alkaline conditions ${ }^{2}$. Remazol dyes initially do not contain free vinylsulfone groups but instead contain non-reactive $\beta$-sulfatoethylsulfone groups, which $\beta$-eliminate during the dyeing process to form the vinylsulfone reactive group, which reacts with nucleophiles (water, alcohols, amines, and cellulose) by a nucleophilic addition reaction ${ }^{3}$. Bifunctional reactive dyes containing a vinylsulfonyl and a monochlorotriazine groups are widely used, and it is known that the two 
reactive groups have different relativities ${ }^{4}$. For vinylsulfonyl (VS) and monochlorotriazine groups, kinetic studies showed the rate of alkaline hydrolysis of the VS group was 3-4 times faster than that of the monochlorotriazine group under equivalent conditions. The different reactivity indicates that the two reactive groups in one molecule can not reach their respective highest fixation simultaneously ${ }^{5}$. VS group is preferable for dyeing in basic medium and it reacts with hydroxide group of water and cellulose in the synthesis of the reactive dye easily.

It is well known that the treatment of suitably substituted azo dyes with metal ions (e.g. $\left.\mathrm{Cr}^{3+}, \mathrm{Cu}^{2+}, \mathrm{Fe}^{3+}\right)$ can improve light and wash fastness properties ${ }^{6,7}$. In this regard, the dyes often form ligand-metal complexes that are less soluble in water than the starting ligands, which contribute to the observed improvement in wash fastness. In the case of medially metallized azo dye complexes, enhanced light fastness arises from protection of the azo bond through back bonding, which utilizes the empty $d$-orbitals of the transition metals employed. Because metal complexes are used for removing heavy metals in wastewater, different functional groups of reactive were investigated recently.

Although reactive dyes are hydrolyzed in aqueous solution, dyes including flour groups are not. The flour does not leave from the molecule readily because of its low reactivity. For this reason, the forming reaction between the dye and the fiber is difficult. The dyeing rate is low, so it penetrates on fiber easily ${ }^{8}$.

If a coupling reaction is managed either in acidic or basic medium, the coupling process should be performed first in acidic and second in basic medium. If the first stage of the reaction is started in alkali medium, the second stage will not occur in acidic condition for coupling. The yield of coupling reaction is higher in acidic medium than that of the basic medium? ${ }^{9}$. When the VS group is linked at the $p$-position to the amino group which has electrophilic character the amino group is reduced because of the conjugation effect. In the case of 3-vinylsulfonylaniline, this effect is significantly decreased due to non-conjugation factors ${ }^{10}$. The highest fixation yield is obtained with the $m$-( $\beta$-sulfatoethyl-sulfonyl) aniline as a reactive group ${ }^{11}$.

Cellulose fibers are important in the textile industry owing to very good quality of fabrics made of them, as well as their low price. More and more attention is paid to enrich the finishing of fabrics to prolong their working life. Cellulose fibers can be dyed with reactive, direct, vat, and sulfur dyes, as well as insoluble azoic dyes forming on fibers. The requirements of today's customers are fully met by the reactive dyes which form covalent bonds with cellulose ${ }^{12,13}$.

Cotton is currently responsible for approximately $50 \%$ of the world's fiber consumption and is expected that its dominant position also will continue in the future. Cotton is dyed with five major classes of the dyes such as the non-ionic vat, sulfur, azoic, anionic direct and reactive. Reactive dyes, which form covalent bonds between the dye and the cellulosic substrate as a result of an alkaline 'fixation' step during dyeing, are the fastest growing class of cellulosic dyestuffs ${ }^{14}$. Since the introduction of reactive dyes for cellulose in the mid1950 s, a large number of different reactive groups have been commercially exploited ${ }^{15}$.

The dyeing of cellulose fibers with vinylsulfone reactive dyes are carried out with addition of reagents such as $\mathrm{NaOH}, \mathrm{NaCl}$, and urea. These chemicals help to optimize the covalent bonding of the dyes to the substrate. The dyeing process is performed in an alkaline medium, which is needed to create the covalent bond between the dye molecule and the ionized hydroxyl group of cellulose. $\mathrm{NaOH}$ is responsible for the formation of the nucleophilic $\left(\right.$ Cell- $\left.\mathrm{O}^{-}\right)$and its addition to the double bond of the vinylsulfone group of the dye. The mechanism is an asymmetric dihydroxylation $\mathrm{S}_{\mathrm{N}} 1$, it takes place in two steps. The first step is the elimination of $\mathrm{H}_{2} \mathrm{SO}_{4}$ and the formation of the double bond and the second step comprises the addition of the Cell- $\mathrm{O}^{-}$to the double bond in the dye ${ }^{16}$. 
In this study, we have synthesized a reactive dye containing vinyl sulfonyl and fluorine groups and its metal complexes with $\mathrm{Cu}(\mathrm{II}), \mathrm{Co}(\mathrm{II}), \mathrm{Cr}(\mathrm{III}), \mathrm{Ni}(\mathrm{II})$ salts (Scheme 5). These dyes were applied to cotton, polyamide, nylon fibers and their fastnesses were examined.

\section{Experimental}

All chemicals were obtained from commercial sources and purified prior to use. FT-IR spectra were recorded on a Perkin Elmer RX I spectrometer as $\mathrm{KBr}$ disc, electronic spectra on Model Shimadzu UVG-54 spectrophotometer in the range 200-400 nm. ${ }^{1} \mathrm{H}-\mathrm{NMR}$ spectra were recorded on a Bruker/XWIN-NMR. Thermal analysis was performed with Perkin Elmer Instruments Technology by SII Pyris Diamond TG/DTA. Methods used to determine fastnesses were Marks \& Spencer-C4A, Marks \& Spencer-C7, Marks \& Spencer-E2, ISO105-B02 for wash, perspiration, friction ${ }_{\text {wet }}$ and light fastnesses respectively.

Preparation of 1-hydroxy-2-(p- $\beta$-sulfatoethylsulfonyl)phenylazo-7-(2,4-difluoro) phenylazo-8-amino-1-naphthol-3,6-disulfonic acid (HL)

\section{Step 1. Preparation of Diazotization of 2,4-difluoro aniline}

2,4-Difluoro aniline (1 mmol) was dissolved in $3 \mathrm{~mL}$ of $\mathrm{H}_{2} \mathrm{O}$ and $3 \mathrm{~mL}$ of $37 \% \mathrm{HCl}$. The reaction was stirred at $0-5^{\circ} \mathrm{C}$ during $15 \mathrm{~min}$. $1 \mathrm{mmol} \mathrm{NaNO}_{2}$ was dissolved in $3 \mathrm{~mL} \mathrm{H}_{2} \mathrm{O}$ and added to 2,4-difluoro aniline solution (Scheme 1).

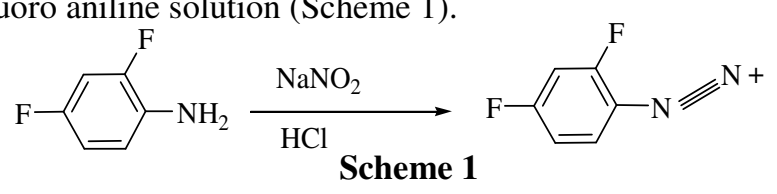

Step 2. Coupling to H-acid (8-amino-1-naphthol-3,6-disulphonicacid)

$\mathrm{H}$-acid (1mmol) was dissolved in $50 \mathrm{~mL}$ of $\mathrm{H}_{2} \mathrm{O}$. Diazonium salt solution was added to $\mathrm{H}$ acid. This reaction was stirred with magnetic stirred for $30 \mathrm{~min}$ at $0-5^{\circ} \mathrm{C}$ (Scheme 2).<smiles>Nc1c(N=Nc2ccc(F)c(F)c2)c(S(=O)(=O)O)cc2cc(S(=O)(=O)O)cc(O)c12</smiles>

Scheme 2

Step 3. Diazotization of 4-( $\beta$-sulfatoethylsulfonyl) aniline

4-( $\beta$-Sulfatoethylsulfonyl)aniline (1mmol) was dissolved in $3 \mathrm{~mL}$ of $\mathrm{H}_{2} \mathrm{O}$ and $3 \mathrm{~mL}$ of $37 \%$ $\mathrm{HCl}$. Reaction was stirred at $0-5^{\circ} \mathrm{C} .1 \mathrm{mmol} \mathrm{NaNO}_{2}$ was dissolved in $3 \mathrm{~mL}$ of $\mathrm{H}_{2} \mathrm{O}$ and added to 4 -( $\beta$-sulfatoethylsulfonyl) aniline solution (Scheme 3$)$

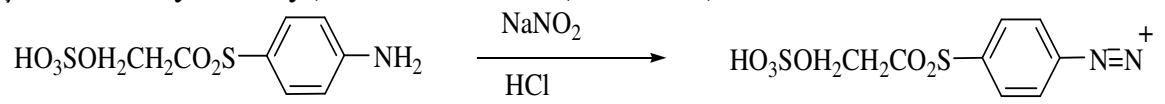

Scheme 3

The first coupling reaction was stirred for $30 \mathrm{~min}$ (Scheme 2) and $\mathrm{pH}$ of the mixture was adjusted with $1 \mathrm{M} \mathrm{NaOH}$ for the second coupling reaction. Diazonium salt solution of 4 - $\left(\beta\right.$-sulfatoethylsulfonyl) aniline was added and stirred at $0-5^{\circ} \mathrm{C}$. The mixture was stirred for 30 min and during the reaction $1 \mathrm{M} \mathrm{NaOH}$ was dropped in slowly. Sodium acetate was used for controlling the reaction whether or not diazotization was complete. At the end of the reaction the product was precipitated. Then, the mixture was filtered and purified. The crude product was dried at $60-80^{\circ} \mathrm{C}$ in an oven. Then it was eluted from silica with 8-amino-1-naphthol-3, 6- 
disulfonicacid $n$-propyl alcohol (30\%) in acetonitrile. The compound which has dye character was obtained as a purple powder (Scheme 4). Yield: $72 \%$. M.P $=214^{\circ} \mathrm{C}$. MW: 859 g.mol ${ }^{-1}$

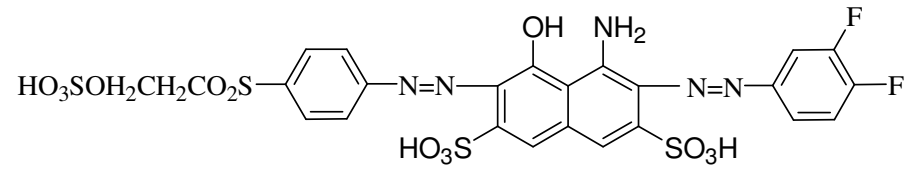

\section{Microanalysis}

\section{Scheme 4}

(Found: C, 31.8; H, 1.8; N, 7.7; S, 14.1\%. $\mathrm{C}_{24} \mathrm{H}_{19} \mathrm{~N}_{5} \mathrm{O}_{13} \mathrm{~S}_{4} \mathrm{~F}_{2} .6 \mathrm{H}_{2} \mathrm{O}$ Requires: $\mathrm{C}, 32.6 ; \mathrm{H}$, $2.1 ; \mathrm{N}, 7.9 ; \mathrm{S}, 14.5: \%)$.

IR $\left(\mathrm{KBr}, \mathrm{cm}^{-1}\right): 3600(\mathrm{Ar}-\mathrm{OH}), 3455(\mathrm{Ar}-\mathrm{N}-\mathrm{H}$ primer peaks), $3233(\mathrm{Ar}-\mathrm{CH}), 2924(\mathrm{Al}-\mathrm{CH})$, $1617(\mathrm{Ar}-\mathrm{C}=\mathrm{C}), 1498(\mathrm{~N}=\mathrm{N}), 1138-1050$ (asymmetric and symmetric sulfonyl groups).

UV-Vis $\left(\mathrm{H}_{2} \mathrm{O}, \mathrm{nm}\right)$ : 230 (aromatic band), 313 (naphthalene $\mathrm{B}$ band), $588(\mathrm{~N}=\mathrm{N}$, azo group).

${ }^{1} \mathrm{H}-\mathrm{NMR}$ (DMSO-d6,ppm):7.2( $\left.\mathrm{Ar}^{1}-\mathrm{H}\right), 7.1\left(\mathrm{Ar}^{1}-\mathrm{H}\right), 6.8\left(\mathrm{Ar}^{1}-\mathrm{H}\right), 7.9\left(\mathrm{Ar}^{11}-\mathrm{H}\right), 7.4\left(\mathrm{Ar}^{11}-\mathrm{H}\right), 15\left(\mathrm{Ar}^{11}-\mathrm{OH}\right)$, 3.9( $\left.\mathrm{Ar}^{\mathrm{II}}-\mathrm{NH}\right), 6.3\left(\mathrm{Ar}^{\mathrm{III}}-\mathrm{H}\right), 6.2\left(\mathrm{Ar}^{\mathrm{III}}-\mathrm{H}\right), 3.4(\mathrm{R}-\mathrm{H}), 3.3(\mathrm{R}-\mathrm{H}), 10.5(\mathrm{R}-\mathrm{OH}), \mathrm{Ar}^{1}$ : aromatic structure bounding Fluorine, $\mathrm{Ar}^{\mathrm{I1}}: \mathrm{H}$-acid, $\mathrm{Ar}^{\mathrm{III}}: 1$-amminobenzen-4- $\beta$-sulfatoethylsulfone (Figure 1,2 and 3).

1-Hydroxy-2-(p- $\beta$-sulfatoethylsulfonyl)phenylazo-7-(2,4-difluoro) phenylazo-8amino-1-naphthol-3,6-disulfonic acid-Cr

Its colour is lilac. Yield: $52 \%$. IR $\left(\mathrm{KBr} \mathrm{cm}^{-1}\right)$ : 3450 (Ar-OH and $\mathrm{NH}_{2}$ overlapping), 3131 $(\mathrm{Ar}-\mathrm{CH}), 3055(\mathrm{Al}-\mathrm{CH}), 1638(\mathrm{Ar}-\mathrm{C}=\mathrm{C}), 1560(\mathrm{~N}=\mathrm{N}), 1138-1049$ (asymmetric and symmetric sulfonyl groups), 646 (Cr-O).UV-Vis (Water,nm): 230 (aromatic band), 313 (naphthalene B band), 565 ( $\mathrm{N}=\mathrm{N}$, azo group). Magnetic Susceptibility: n: 3, Requires (AAS): $\mathrm{Cr} \%: 7.2$, Found: $\mathrm{Cr} \%: 5.6$

1-Hydroxy-2-(p- $\beta$-sulfatoethylsulfonyl)phenylazo-7-(2,4-difluoro) phenylazo-8amino-1-naphthol-3,6-disulfonic acid-Ni

Its colour is violet. Yield: $56 \%$. IR $\left(\mathrm{KBr} \mathrm{cm}^{-1}\right)$ : 3452 (Ar-OH and $\mathrm{NH}_{2}$ overlapping), 3059 (Ar-CH), 2997 (Al-C-H stretching), $1640($ Ar-C=C), $1557(\mathrm{~N}=\mathrm{N}$, azo group), 1139-1048 (asymmetric and symmetric sulfonyl groups), 653 (Ni-O). UV-Vis (Water,nm): 230 (aromatic band), 316 (naphthalene $\mathrm{B}$ band), $588(\mathrm{~N}=\mathrm{N}$, azo group). Requires (AAS): Ni \%: 8.4, Found: Ni \%: 9,5 (TG), Magnetic Susceptibility: n: 2.

1-Hydroxy-2-(p- $\beta$-sulfatoethylsulfonyl)phenylazo-7-(2,4-difluoro) phenylazo-8amino-1-naphthol-3,6-disulfonic acid-Co

Its colour is light brown. Yield: $63 \%$. IR $\left(\mathrm{KBr} \mathrm{cm}^{-1}\right)$ : 3451 ( $\mathrm{Ar}-\mathrm{OH}$ and $\mathrm{NH}_{2}$ overlapping), 3057 (Ar-CH), 2919 (Al-C-H stretching), 1647 (Ar $\mathrm{C}=\mathrm{C}), 1560 \quad(\mathrm{~N}=\mathrm{N}), 1136-1047$ (asymmetric and symmetric sulfonyl groups), 655 (Co-O). UV-Vis (Water,nm): 236 (aromatic band), 341 (naphthalene B band), 531 ( $\mathrm{N}=\mathrm{N}$, azo group). Requires (AAS): Co \%: 7.7, Found: Co \%: 6.4, Magnetic Susceptibility: n: 3.

1-Hydroxy-2-(p- $\beta$-sulfatoethylsulfonyl)phenylazo-7-(2,4-difluoro) phenylazo-8amino-1-naphthol-3,6-disulfonic acid-Cu

Its colour is pink. Yield: $62 \%$. IR $\left(\mathrm{KBr} \mathrm{cm}^{-1}\right): 3589$ (Ar-OH ve $\mathrm{NH}_{2}$ overlapping), 3020 ( $\mathrm{Ar}$ $\mathrm{C}-\mathrm{H}), 2865(\mathrm{Al}-\mathrm{CH}), 1664(\mathrm{Ar} \mathrm{C}=\mathrm{C}), 1490(\mathrm{~N}=\mathrm{N}), 1140-1055$ (asymmetric and symmetric sulfonyl groups), $738(\mathrm{Cu}-\mathrm{O})$. UV-Vis (Water,nm): 235 (aromatic band), 348 (naphthalene $\mathrm{B}$ band), 517 (N=N, azo group). Requires (AAS): $\mathrm{Cu} \%$ : 1.5, Found: $\mathrm{Cu} \%: 3.8$, Magnetic Susceptibility: n: 2 
Synthesis of Compounds Containing Fluorine and Vinylsulfone Groups 1001

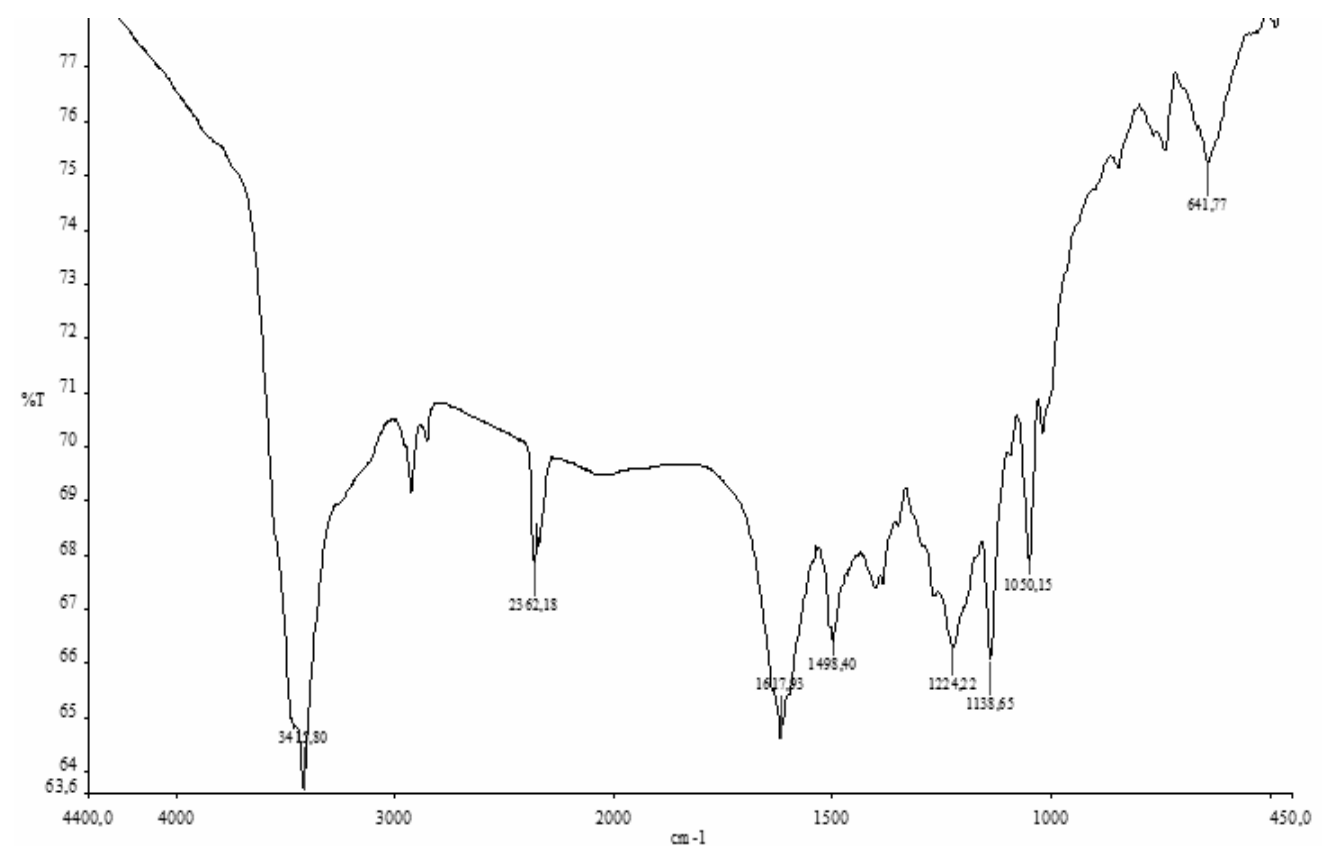

Figure 1. FT-IR of 1-hydroxy-2-( $p$ - $\beta$-sulfatoethylsulfonyl)phenylazo-7-(2,4-difluoro)

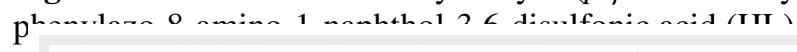

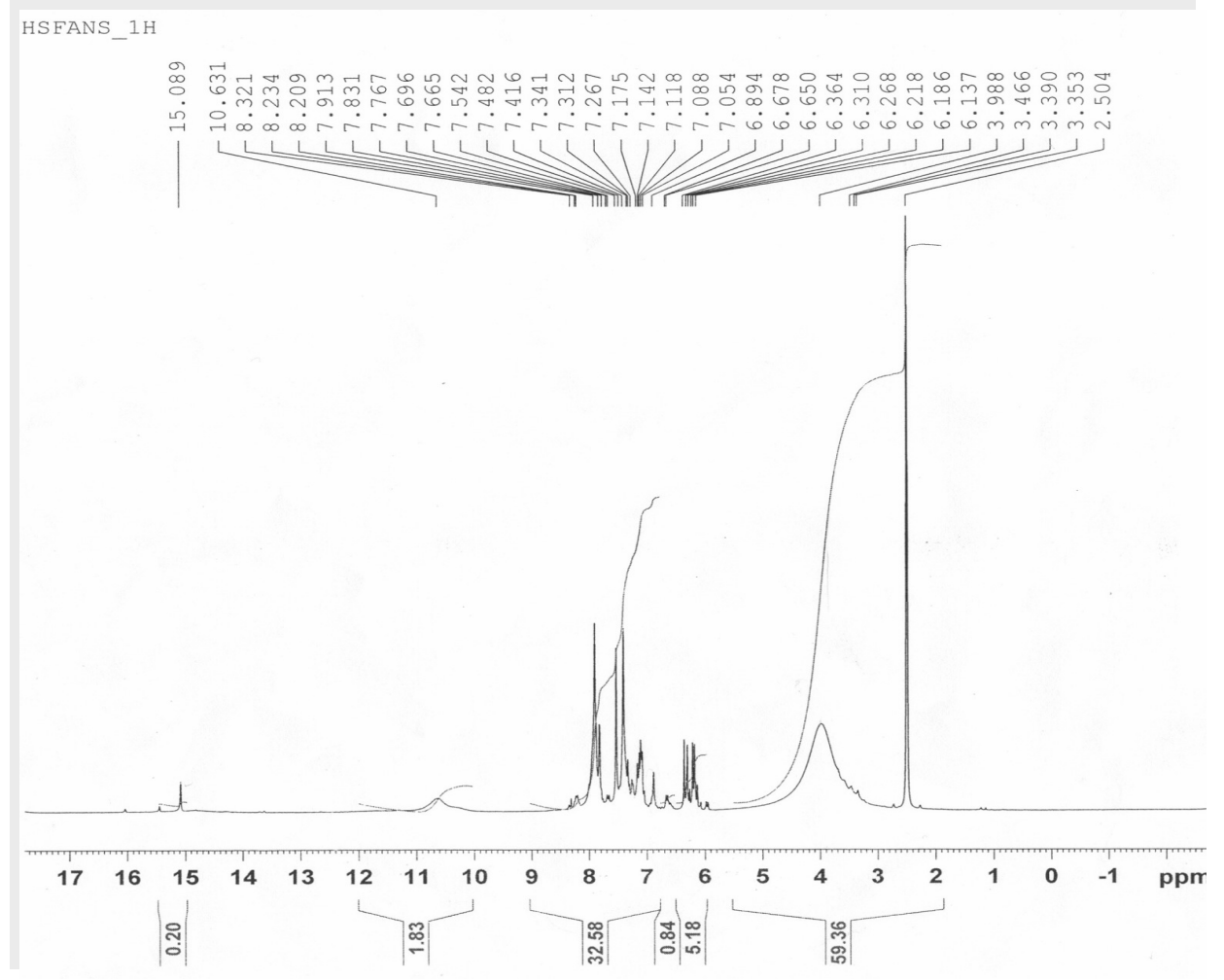

Figure 2. ${ }^{1} \mathrm{H}-\mathrm{NMR}$ of the ligand (HL). 


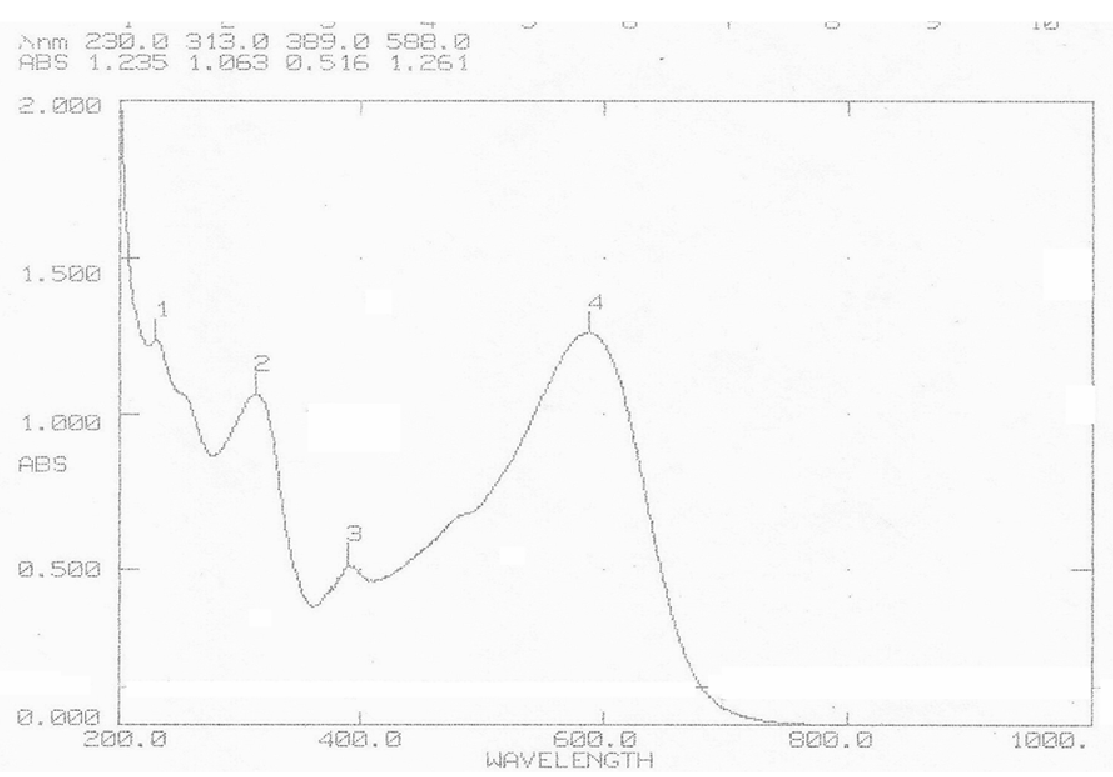

Figure 3. UV spectrum of the HL

General method for the preparation of metal complexes of 1-hydroxy-2-(p- $\beta$ sulfatoethylsulfonyl) phenylazo-7-(2,4-difluoro) phenylazo-8-amino-1-naphthol-3,6disulfonic acid

$1 \mathrm{mmol} \mathrm{CuCl} 2.2 \mathrm{H}_{2} \mathrm{O}\left(\mathrm{CoCl}_{2} \cdot 6 \mathrm{H}_{2} \mathrm{O}, \mathrm{NiCl}_{2} \cdot 6 \mathrm{H}_{2} \mathrm{O}, \mathrm{CrCl}_{3} \cdot 3 \mathrm{H}_{2} \mathrm{O}\right)$ was dissolved in $10 \mathrm{~mL} \mathrm{H}_{2} \mathrm{O}$ and added to $1 \mathrm{mmol}$ dye solution dissolved in $50 \mathrm{~mL} \mathrm{H}_{2} \mathrm{O}$. The solution was stirred for 6 hours at $\mathrm{pH} 3$ with magnetic stirring under reflux. After the reaction completed the $\mathrm{pH}$ was adjusted to 6 with $1 \mathrm{M} \mathrm{NaOH}$ and the product precipitated. Then the mixture was filtered, purified and the product was dried at $60-80^{\circ} \mathrm{C}$ (Scheme 5).
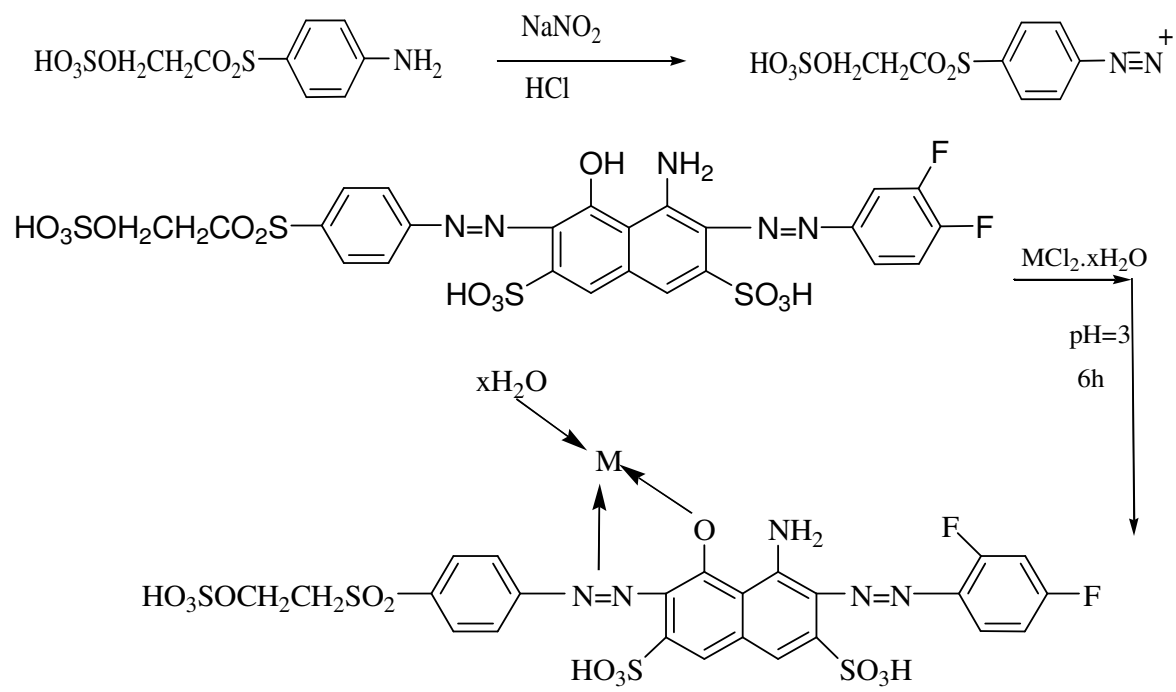

Scheme 5 


\section{Applications and dyeing properties}

\section{Dyeing}

Each solution $(50 \mathrm{~mL})$ was prepared with dye for $5 \mathrm{~g}$ cotton, polyamide and nylon. $1 \mathrm{~g} \mathrm{Na}_{2} \mathrm{SO}_{4}$ and $0,025 \mathrm{~g}$ dye were dissolved in water. The temperature of each dye bath was raised to $60^{\circ} \mathrm{C}$, and $5 \mathrm{~g}$ cotton was immersed in the dye bath for $30 \mathrm{~min}$ with stirring to permit primary exhaustion. 0,5 $\mathrm{g} \mathrm{Na}_{2} \mathrm{CO}_{3}$ was then added and dyeing was continued for a further 45-60 min at $60^{\circ} \mathrm{C}$ to permit secondary exhaustion. After dyeing, the cotton was washed in $75 \mathrm{~mL}$ boiling water at $95^{\circ} \mathrm{C}$ and cold water twice. Then, the cotton fiber was washed with $0,3 \mathrm{~g}$ detergent in $75 \mathrm{~mL}$ boiling and cold water twice. The fiber was dried. The bath temperature was $80^{\circ} \mathrm{C}$ for viscon and nylon fibers which were dyed with metal complex dyes.

\section{Wash fastness}

$5 \mathrm{~g}$ Sodiumperborate tetrahydrate and $20 \mathrm{~g}$ detergent were dissolved in $250 \mathrm{~mL}$ water. $5 \mathrm{~g}$ Cotton and multifibre were sewn together and immersed in the washing bath for $30 \mathrm{~min}$. The mixture was stirred at $65^{\circ} \mathrm{C}$. Then, the cotton and multifibre were rinsed and dried. The multifibre was evaluated as a grey scale.

\section{Perspiration fastness}

$2 \mathrm{~g} \mathrm{Na}_{2} \mathrm{HPO}_{4} \cdot 2 \mathrm{H}_{2} \mathrm{O}, 5 \mathrm{~g}$ 1-histidine monohydrochloride monohydrate and $5 \mathrm{~g} \mathrm{NaCl}$ were dissolved in $1000 \mathrm{~mL}$ water. The cotton and multifibre were cut into $5 \mathrm{~cm}$ in width, $5 \mathrm{~cm}$ in length. They were sewed together and put in Petri dish. The solution was poured into the Petri dish and allowed to stand for $30 \mathrm{~min}$. Then, they were dried in the drying oven for $4 \mathrm{~h}$ at $37^{\circ} \mathrm{C}$. Later, the cotton and the multifibre were separated from each other and placed on white paper and again dried in the drying oven at $60^{\circ} \mathrm{C}$. The multifibre was evaluated with a grey scale.

\section{Friction fastness}

A Croc meter was used for this test and evaluated with a grey scale.

\section{Light fastness}

Dying and accompanying fabrics stitched together were held for $90 \mathrm{~h}$ in a light fastness measuring device and evaluated with a blue scale. All these results are shown in Table 3.

\section{Results and Discussion}

In this work, a reactive dye that included vinylsulfone and fluoride groups and its metal complexes such as $\mathrm{Cu}(\mathrm{II}), \mathrm{Co}(\mathrm{II}), \mathrm{Cr}(\mathrm{III})$ and $\mathrm{Ni}(\mathrm{II})$ were synthesized. All synthesized dyes were used for dyeing of cotton, polyamide and nylon fibers.

2,4-Difloroaniline and $p$-( $\beta$-sulfatoetylsulfonyl)aniline were diazotized and final product was coupled with H-acid. 1-hydroxy-2-( $p$ - $\beta$-sulfatoethylsulfonyl) phenylazo-7-(2,4-difluoro) phenylazo-8-amino-1-naphthol-3,6-disulfonic acid which has reactive dye character was obtained. Naphthalene B and $-\mathrm{N}=\mathrm{N}$ - band assigned at $313 \mathrm{~nm}$ and $588 \mathrm{~nm}$ respectively in UVvisible spectra of the ligand. Its TG-DTA analysis showed that experimental mass loss were $5 \%, 24 \%, 11 \% \& 47 \%$ and theoretically these values were calculated for $\mathrm{F}_{2}, \mathrm{C}_{8} \mathrm{H}_{8} \mathrm{SO}_{2} \mathrm{~N}$, $\mathrm{C}_{6} \mathrm{H}_{3} \mathrm{~N}, \mathrm{C}_{10} \mathrm{H}_{5} \mathrm{~S}_{2} \mathrm{~N}_{2} \mathrm{O}_{7} \mathrm{Na}_{2}$ groups as $4.8 \%, 22.9 \%, 11.2 \%$ and $47.1 \%$ respectively.

${ }^{1} \mathrm{H}-\mathrm{NMR}$ data showed aromatic ring protons 7.2, 7.1, 6.3 and $6.2 \mathrm{ppm}$ as doublet peaks. Singlet peaks were observed at 7.9, 7.4 and $6.8 \mathrm{ppm}$. - $\mathrm{OH}$ bridge between intramolecular and free $-\mathrm{OH}$ proton in intermolecular assigned at 15 and $10.5 \mathrm{ppm}^{9}$. Its fastnesses which have fairly good results were determined. 
1-Hydroxy-2-( $p$ - $\beta$-sulfatoethylsulfonyl)phenylazo-7-(2,4-difluoro) phenylazo-8-amino1-naphthol-3,6-disulfonic acid-Cr: As shown in Table 1, In its FT-IR spectra, $1560 \mathrm{~cm}^{-1}$ and $3450 \mathrm{~cm}^{-1}$ peaks are assigned $-\mathrm{N}=\mathrm{N}$ - azo group and water which overlapped the Ar-NH group peak. The $\mathrm{Ar}-\mathrm{CH}, \mathrm{Al}-\mathrm{CH}, \mathrm{Ar}-\mathrm{C}=\mathrm{C}$, asymmetric and symmetric sulfonyl groups are observed at $3131 \mathrm{~cm}^{-1}, 3055 \mathrm{~cm}^{-1}, 1638 \mathrm{~cm}^{-1}$ and $1138-1049 \mathrm{~cm}^{-1}$ respectively. Also, the peak at $646 \mathrm{~cm}^{-1}$ is showed $\mathrm{Cr}-\mathrm{O}$ bond.

Table 1. FT-IR spectra of synthesized dyes $\left(\mathrm{KBr}, \mathrm{cm}^{-1}\right)$

\begin{tabular}{ccccccccc}
\hline Compounds & Ar-NH & Ar-OH & Al-CH & Ar-C=C & Ar-CH & -N=N- & $\begin{array}{c}\text { Asymmetric } \\
\text { sulfonyl group }\end{array}$ & M-O \\
\hline HL & 3455 & 3600 & 2924 & 1617 & 3233 & 1498 & $1138-1050$ & - \\
L-Cr & 3450 & - & 3055 & 1638 & 3131 & 1560 & $1138-1049$ & 646 \\
L-Co & 3451 & - & 2919 & 1647 & 3057 & 1560 & $1136-1047$ & 655 \\
L-Ni & 3452 & - & 2997 & 1640 & 3059 & 1557 & $1139-1048$ & 653 \\
L-Cu & 3589 & - & 2865 & 1664 & 3020 & 1490 & $1140-1055$ & 738 \\
\hline
\end{tabular}

The absorption bands which are observed at $230 \mathrm{~nm}, 313 \mathrm{~nm}$ and $565 \mathrm{~nm}$ were assigned aromatic structures, naphthalene $\mathrm{B}$ band and forming $-\mathrm{N}=\mathrm{N}$ - bond in $\mathrm{UV}$-visible spectra (Table 2).

Table 2. UV-visible spectra of synthesized dyes

\begin{tabular}{|c|c|c|c|c|c|c|}
\hline \multirow[t]{2}{*}{ Compounds } & \multicolumn{2}{|c|}{ Aromatic band } & \multicolumn{2}{|c|}{ Naphthalene B hand } & \multicolumn{2}{|c|}{$-\mathrm{N}=\mathrm{N}-$} \\
\hline & $\lambda, \mathrm{nm}$ & $\varepsilon \max$ & $\Lambda, \mathrm{nm}$ & $\varepsilon \max$ & $\Lambda, \mathrm{nm}$ & $\varepsilon \max$ \\
\hline HL & 230 & 4700 & 313 & 21260 & 588 & 25220 \\
\hline $\mathrm{L}-\mathrm{Cr}$ & 230 & 11310 & 313 & 8680 & 565 & 8830 \\
\hline L-Co & 236 & 12300 & 341 & 5540 & 531 & 2850 \\
\hline L-Ni & 230 & 14870 & 316 & 12600 & 588 & 14840 \\
\hline $\mathrm{L}-\mathrm{Cu}$ & 235 & 13560 & 348 & 6180 & 517 & 4570 \\
\hline
\end{tabular}

The metal ligand ratio is estimated as 1:1 with regards Job's method in L-Cr complex. This metal complex dye was applied on nylon and viscon fibers and good results were obtained for their fastness as shown in Table 3.

Table 3. Fastness results of synthesized dyes (c: cotton, v: viscon)

\begin{tabular}{lcccccc}
\hline $\begin{array}{c}\text { Synthesized } \\
\text { Dyes }\end{array}$ & $\begin{array}{c}\text { Wash } \\
\text { Fastness }\end{array}$ & $\begin{array}{c}\text { Perspiration } \\
\text { Fastness }\end{array}$ & $\begin{array}{c}\text { Friction, wet } \\
\text { Fastness }\end{array}$ & $\begin{array}{c}\text { Friction, dry } \\
\text { Fastness }\end{array}$ & $\begin{array}{c}\text { Light } \\
\text { Fastness }\end{array}$ & $\begin{array}{c}\text { Stain in } \\
\text { Nylon }\end{array}$ \\
\hline HL (c) & 5 & $4-5$ & $4-5$ & 5 & $4-5$ & - \\
HL (v) & 5 & $4-5$ & $4-5$ & 5 & $4-5$ & - \\
L-Co(v) & 5 & 5 & $4-5$ & 5 & $4-5$ & 4 \\
L-Cr(v) & 5 & 5 & $4-5$ & 5 & $3-4$ & 3 \\
L-Ni (v) & 5 & $4-5$ & $4-5$ & 5 & $3-4$ & $3-4$ \\
L-Cu(v) & $4-5$ & $4-5$ & $4-5$ & 5 & $4-5$ & $4-5$ \\
\hline
\end{tabular}

1-Hydroxy-2-( $p$ - $\beta$-sulfatoethylsulfonyl)phenylazo-7-(2,4-difluoro) phenylazo-8-amino1-naphthol-3,6-disulfonic acid-Cu: Numerous dimeric copper (II) compounds with different non-magnetic ligands have been studied recently. According to Job's method and the magnetic susceptibility value of the $\mathrm{L}-\mathrm{Cu}$ complex, which has free valance electron and is paramagnetic, leads to the conclusion that the $\mathrm{L}-\mathrm{Cu}$ complex has dimeric structure ${ }^{17,18}$. 
A fluorine group incorporated in the synthesized dyes is not a good leaving group ${ }^{9}$. For this reason, their friction ${ }_{\text {wet }}$ and wash fastnesses have high values. The all fastnesses of cooper complex dye are better than that of $\mathrm{Cr}$ (III) and $\mathrm{Ni}$ (II) complex dyes.

1-Hydroxy-2-( $p$ - $\beta$-sulfatoethylsulfonyl)phenylazo-7-(2,4-difluoro) phenylazo-8-amino1-naphthol-3,6-disulfonic acid-Co:; the peak of $-\mathrm{N}=\mathrm{N}$ - azo group is at $1560 \mathrm{~cm}^{-1}$ in FT-IR spectra. Overlapping of Ar-NH and water peaks are recorded at $3451 \mathrm{~cm}^{-1}$. The peaks are $\mathrm{Ar}-\mathrm{CH}, \mathrm{Al}-\mathrm{CH}, \mathrm{Ar}-\mathrm{C}=\mathrm{C}$, asymmetric and symmetric sulfonyl group vibrations at $3057 \mathrm{~cm}^{-1}$, $2919 \mathrm{~cm}^{-1}, 1647 \mathrm{~cm}^{-1}$ and $1136-1047 \mathrm{~cm}^{-1}$ respectively. The peak at $655 \mathrm{~cm}^{-1}$ is assignment of Co-O bond. In UV-visible spectra, maximum absorption bands which are observed 236 $\mathrm{nm}, 341 \mathrm{~nm}$ and $531 \mathrm{~nm}$ are showed aromatic naphthalene $\mathrm{B}$ bands and $-\mathrm{N}=\mathrm{N}$ - group.

Job's method showed that the metal ligand ratio is 1:1 for the L-Co complex. This dye was applied on nylon and viscon fibers and obtained good fastnesses for both of them.

1-Hydroxy-2-( $p$ - $\beta$-sulfatoethylsulfonyl)phenylazo-7-(2,4-difluoro) phenylazo-8-amino1-naphthol-3,6-disulfonic acid-Ni: The FT-IR spectra show $-\mathrm{N}=\mathrm{N}$ - azo group assigned at $1557 \mathrm{~cm}^{-1}$. The observed peak at $3452 \mathrm{~cm}^{-1}$ was assigned for overlapping Ar-NH and water peaks. The peaks at $3059 \mathrm{~cm}^{-1}, 2997 \mathrm{~cm}^{-1}, 1640 \mathrm{~cm}^{-1}$ and $1139-1048 \mathrm{~cm}^{-1}$ are the Ar-CH, Al$\mathrm{CH}, \mathrm{Ar}-\mathrm{C}=\mathrm{C}$, asymmetric and symmetric sulfonyl groups. The peak at $653 \mathrm{~cm}^{-1}$ is assigned to $\mathrm{Ni}-\mathrm{O}$ bond. In the UV-visible spectrum, the peak at $588 \mathrm{~nm}$ is the characteristic $-\mathrm{N}=\mathrm{N}$ bond. Job's method showed the metal ligand ratio is 1:1 for L-Ni complex.

This metal complex having dye character was applied on nylon and viscon fibers. For all them, good fastnesses were obtained. The TG-DTA analyses showed that the experimental mass losts were $20 \%, 5 \%, 10 \%$ and $45 \%$. Theoretically, these values were $20.5 \%, 4.7 \%, 9.99 \%$ and $42.4 \%$ and interpreted as $\mathrm{C}_{8} \mathrm{H}_{8} \mathrm{SO}_{2} \mathrm{~N}, \mathrm{~F}_{2}, \mathrm{C}_{6} \mathrm{H}_{3} \mathrm{~N}, \mathrm{C}_{10} \mathrm{H}_{5} \mathrm{~S}_{2} \mathrm{~N}_{2} \mathrm{O}_{7} \mathrm{Na}_{2}$ groups (Figure 4,5 and 6).

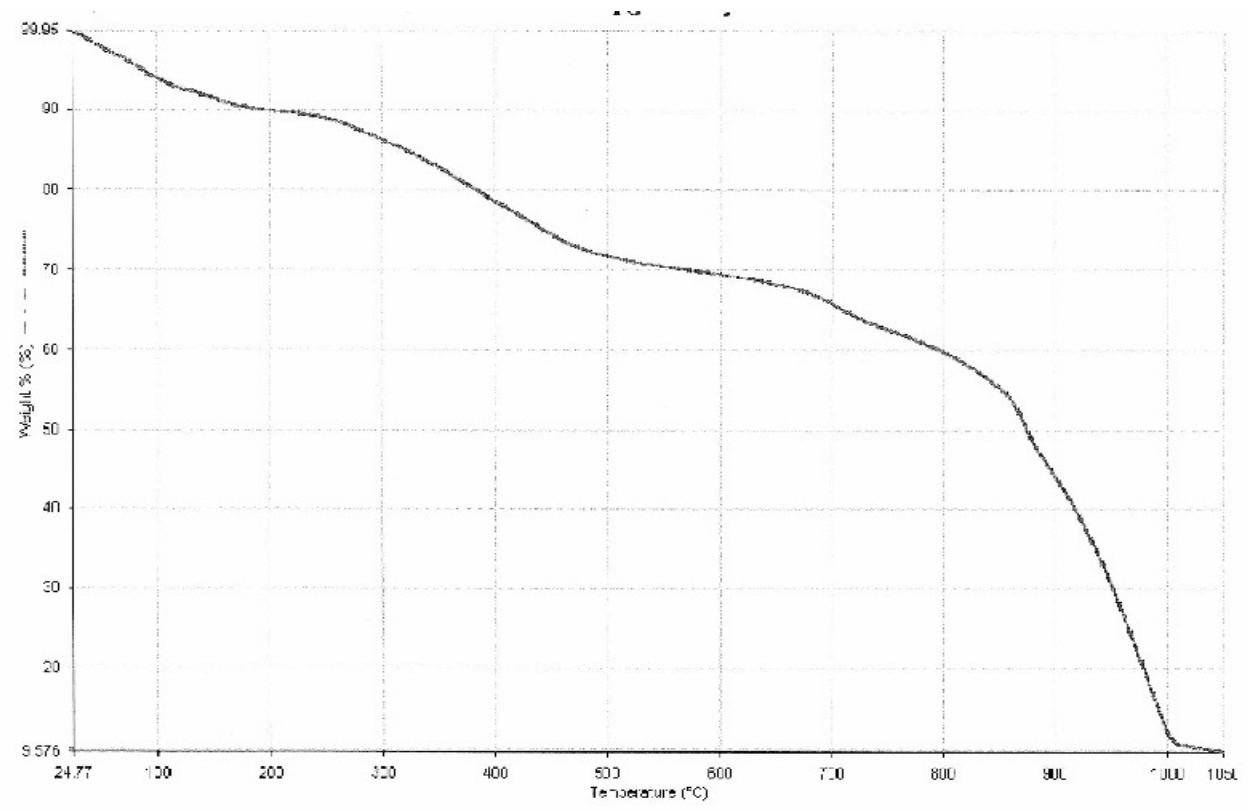

Figure 4. TG of the L-Ni. 


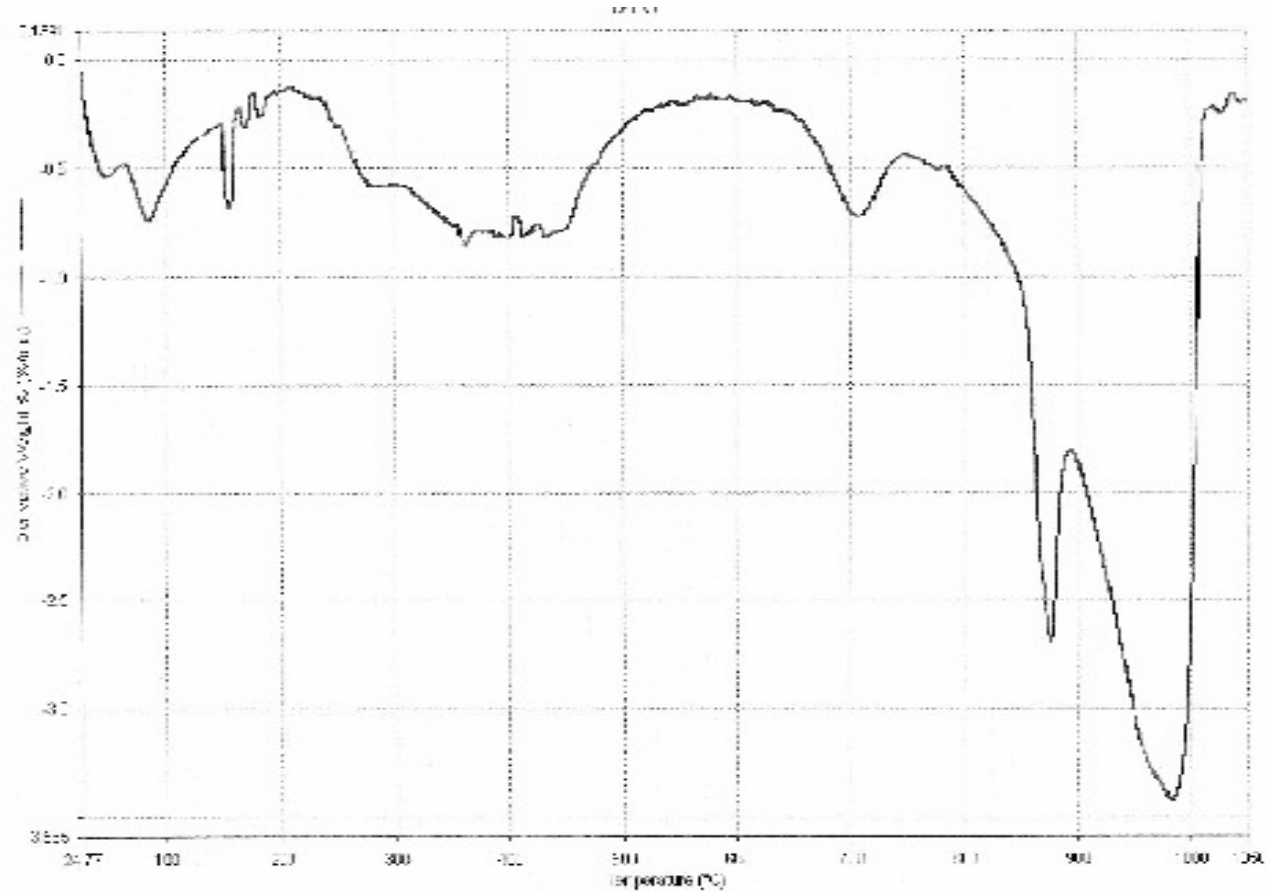

Figure 5. DTG of the L-Ni

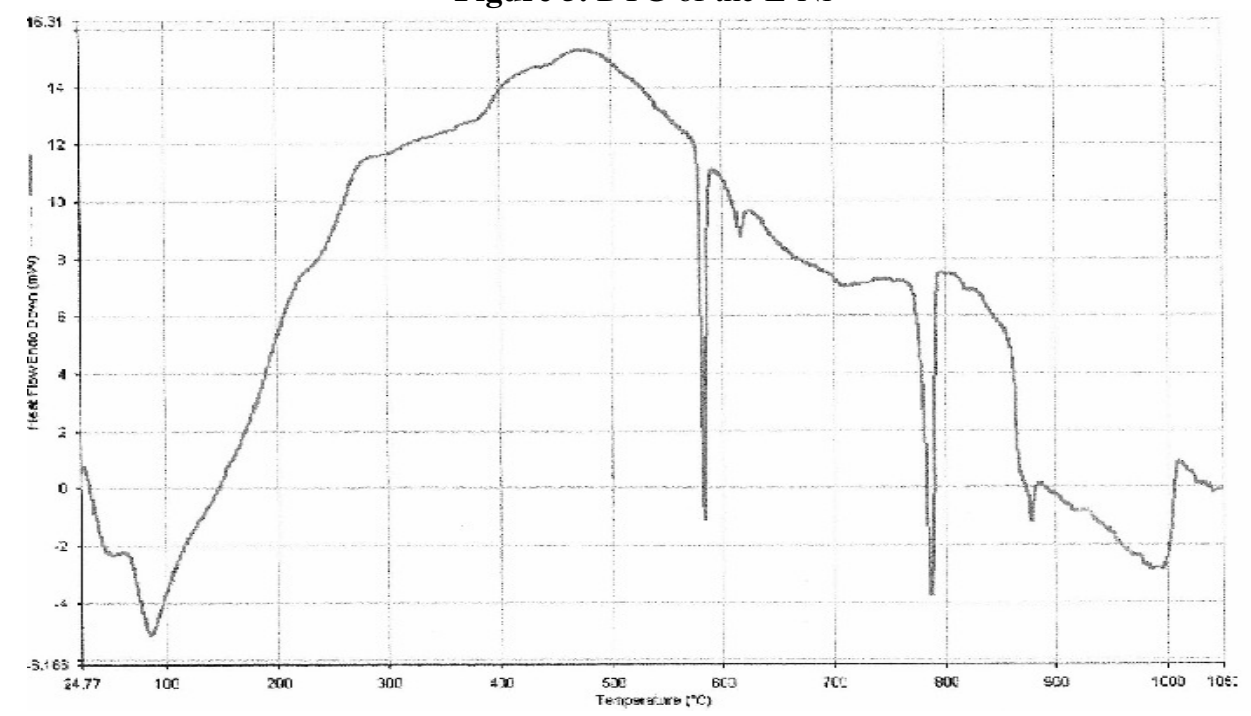

Figure 6. DTA of the L-Ni

1-Hydroxy-2-( $p$ - $\beta$-sulfatoethylsulfonyl)phenylazo-7-(2,4-difluoro) phenylazo-8-amino-1naphthol-3,6-disulfonic acid-Cu: Its colour is pink. The $-\mathrm{N}=\mathrm{N}$ - azo group is located at 1490 $\mathrm{cm}^{-1}$ in FT-IR spectrum. The $\mathrm{Cu}-\mathrm{O}$ bond vibration was observed at $738 \mathrm{~cm}^{-1}$. For the same group, it was indicated at $517 \mathrm{~nm}$ in UV-visible spectra as shown in Table 2. Job's method and result of its magnetic susceptibility were showed that $\mathrm{L}-\mathrm{Cu}$ complex is a dimeric structure.

This compound having dye character was applied on nylon and viscon fibers and good fastnesses were obtained. 


\section{Conclusion}

Synthesized compounds which have dye character have high molecular weights and when they are applied to fabrics their fixes will be slow. For that reason, it is possible to obtain a good dyeing. Because fluorine groups are difficult to remove from the dye molecule and have high electronegativities, the dye will stick to the fabric strongly and maintain good wash fastness at high value. Our fastness results support to this principle. $\mathrm{Cu}$ and Co-complexes of the reactive dyes reported here have good fastnesses and greater than other dyes. As shown in Table 3, the best complex dye is the copper complex in according to the staining of nylon.

Although results of micro analyses for all the metal complexes showed they were not purified completely, they have good dyeing properties as reactive dyes for applying to textiles.

\section{Acknowledgements}

This present work was supported by Research Grants of FEF 2004 YL43 from Cukurova University. The authors would like to thanks Cukurova University, (This paper was represented in XIX. National Chemistry Congress, Turkiye, ANP128, ANP129, Sept, 2005).

\section{References}

1. Aspland J R, Textile Chemist and Colorist,1992, 24, 31 .

2. Lewis D M, Renfrew A H and Siddique A A, Dyes and Pigments, 2000, 47, 151

3. Wilcock C C and Tattersfield C P, J Soc Dyers Colour, 1943, 59, 119.

4. $\quad$ Sheng Y and Zhenghua Z, Dyes and Pigments, 1996, 36, 27.

5. Limin J and Zhenghua Z, Dyes and Pigments, 1997, 36, 347.

6. Perkins W S, Textile coloration and finishing; North Corolina: Corolina Academic Press Durham, 1996, 123.

7. Ergenç N, Aktif Metilen Bileşiklerinin Diazonyum Tuzları ile Kenetlenme Ürünlerinde Spektral Veriler, Spektroskopi 88 Yaz Okulu Seminer Notları, Trabzon, 1988, 160.

8. Shenai V A Technology of Textile Processing, Chemistry of Dyes and Principles of Dying; Sevak Publications: Bombay, 1973, 2.

9. Zhenghua Z, Dyes and Pigments, 1993, 23, 91.

10. Liqi H, Zhenghua Z, Kongchang C and Faxiang Z, Dyes and Pigments, 1989, 10, 195.

11. Das P, J Soc Dyers Colour, 1996, 112,183.

12. Lukos A, Ornaf W, Barwniki reaktywne Budowa zastosowanie (Reactive Dyes. Structure and Application); WPL: Warszawa, 1966.

13. Store J, Colorants and auxiliaties Organic Chemistry and application properties. Society of Dyers and Colourists: Anglija, 1990, 307.

14. Kelshaw P, J Soc Dyers Colour, 1998, 114, 35.

15. Madaras G W, Parish G J and Shore J, Batchwise dyeing of woven cellulosic fabric. Society of dyers and colourists: Bracford, 1993, 31.

16. Venkataraman K, The Chemistry of Synthetic Dyes; Acedemic Press: New York and London, 1972, 6.

17. Heyna J, Angewandte Chemie International, 1963, 2, 20.

18. Jaglicic Z, Segedin P and Zlatic J, J Magnetism and Magnetic Materials, 2007, 310,1444.

19. Moncol J, Inorganica Chimica Acta, 2007, 360, 3213. 


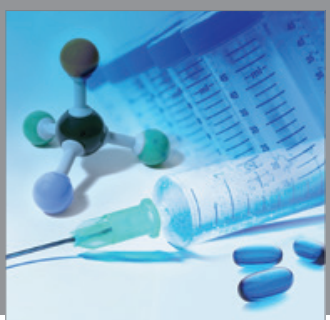

International Journal of

Medicinal Chemistry

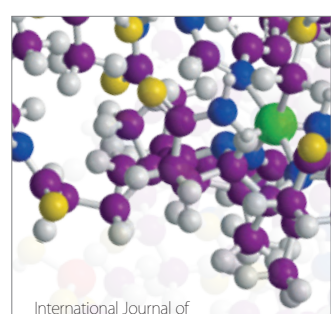

Carbohydrate Chemistry

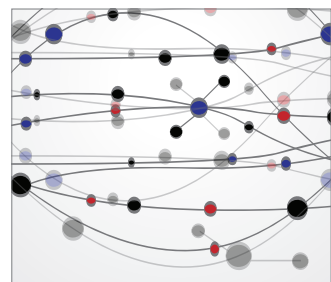

The Scientific World Journal
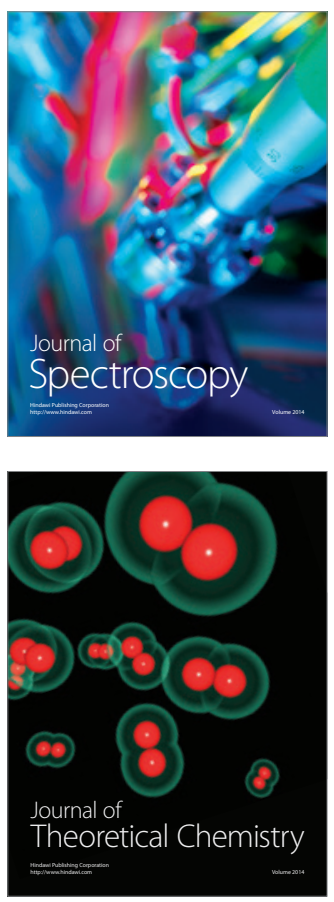
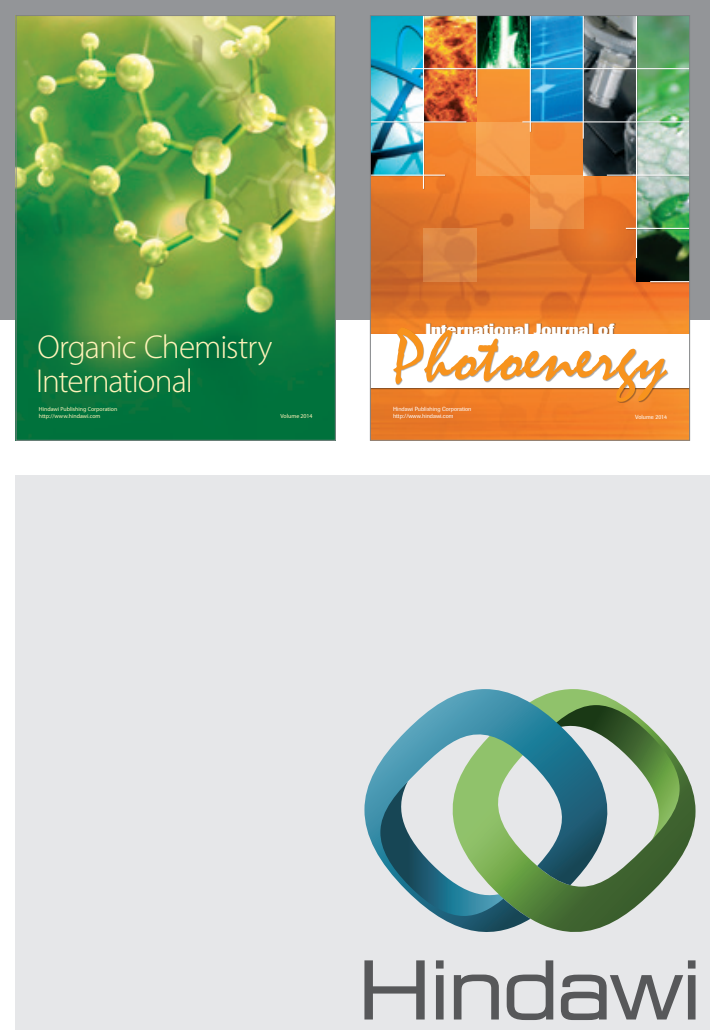

Submit your manuscripts at

http://www.hindawi.com
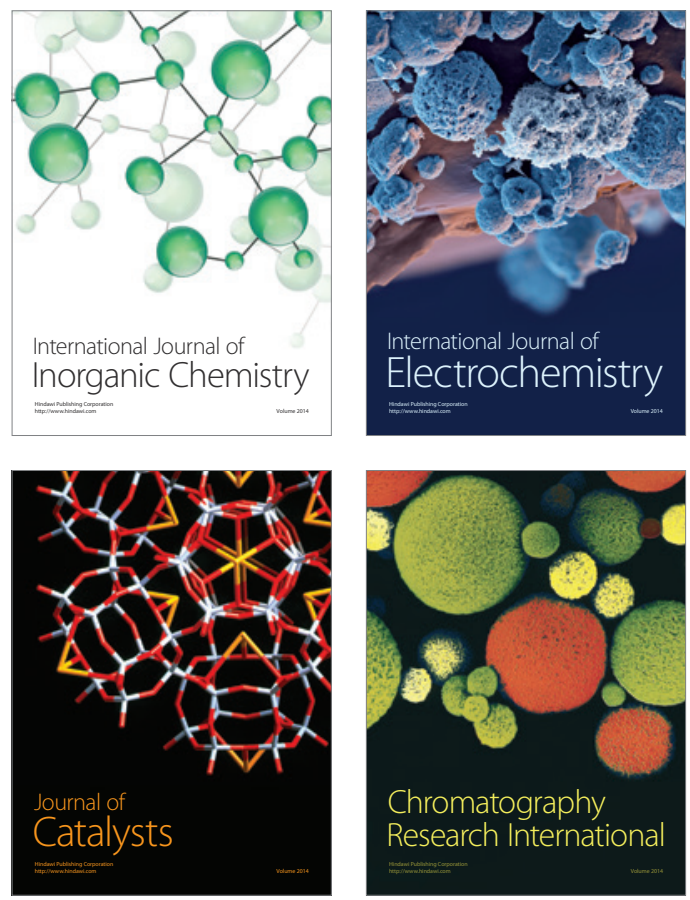
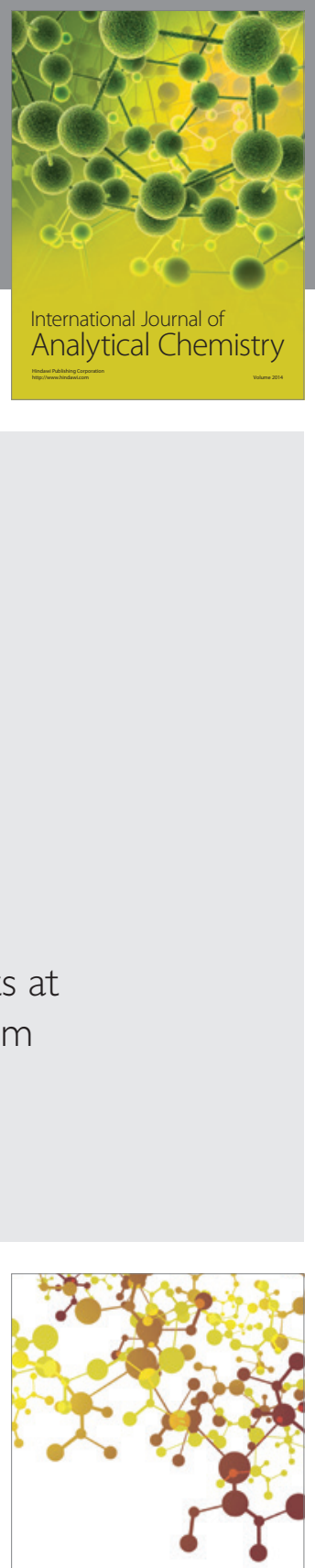

Journal of

Applied Chemistry
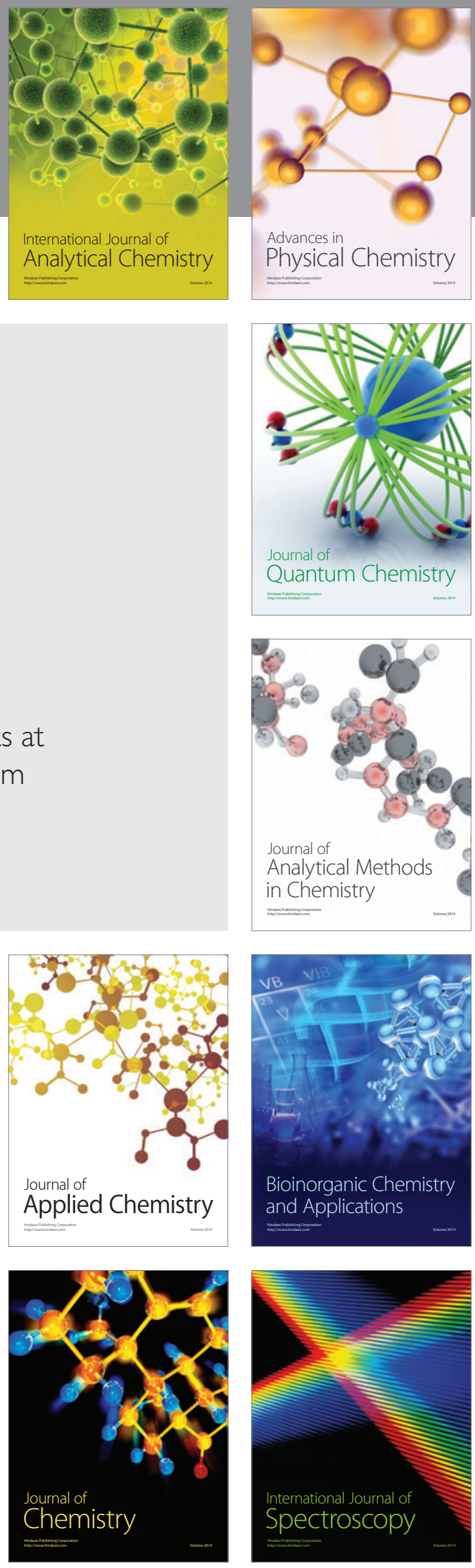